\title{
Screening of Flavonoids in Selected High Valued Medicinal Plants (HVM) of Tirumala, India
}

\author{
R.K. Sreelatha Devi* and S.K.M. Basha \\ Department of Botany, Rayalaseema University, Kurnool-518007, Andhra Pradesh, India \\ *Corresponding author email id:
}

\begin{tabular}{|c|c|}
\hline & A B S T R A C T \\
\hline Keywords & \multirow{4}{*}{$\begin{array}{l}\text { Flavonoids are the potent therapeutical biochemicals which occur in almost all plant taxa } \\
\text { at variable amounts. In this present article based on the ethnobotanical claims and } \\
\text { literature survey we have investigated the presence and quantified the important flavonoids } \\
\text { in selected taxa inhabitating Tirumala hills. Paper chromatography technique were used for } \\
\text { the detection and the flavonoids like rutin, myricetin, quercetin, kaempferol, luteolin, } \\
\text { apigenin, orientin and vitexin were detected with the help of } \mathrm{R}_{f} \text { values and colour reactions } \\
\text { with chromogenic spray reagents in different propositions. A total of } 20 \text { high valued } \\
\text { medicinal plants (HVM) reported in the present study has wide number of flavonoids and } \\
\text { are greatly used by the various ethenic and folklore communities for curing numerous } \\
\text { diseases or ailments. }\end{array}$} \\
\hline $\begin{array}{l}\text { Flavonoids, } \\
\text { High valued } \\
\text { medicinal plants, } \\
\text { Tirumala Hills }\end{array}$ & \\
\hline Article Info & \\
\hline $\begin{array}{l}\text { Accepted: } \\
\text { 08 March } 2017 \\
\text { Available Online: } \\
10 \text { April } 2017\end{array}$ & \\
\hline
\end{tabular}

\section{Introduction}

Flavonoids are a large group of polyphenolic compounds showing have antioxidative activity, free radical scavenging capacity, coronary heart disease prevention, hepatoprotective, anti-inflammatory, and anticancer activities, while some flavonoids exhibit potential antiviral activities (Kumar and Pandey, 2013).

The growing body of scientific evidence indicates that flavonoids play a beneficial role in disease prevention, however further research in new therapeutic flavonoids should be discovered in different species of plant kingdom and pharmacological assays clinical and epidemiological trials are greatly needed for the dietary benefits (Manipal et al., 2017). There has been increasing interest in the research of flavonoids from dietary sources, due to growing evidence of the versatile health benefits of flavonoids through epidemiological studies. As occurrence of flavonoids is directly associated with human daily dietary intake of antioxidants, it is important to evaluate flavonoid sources in locally available plant taxa and we have put scientific efforts for thoroughly screening for phytochemical constituents.

High valued medicinal plants (HVM) are the most potent medicinal plant taxa used since ancient times to treat different disorders and diseases and are still in the process of mining the therapeutical compounds till to date (SreeLatha Devi, 2017)

The present studies is done on evaluation of Flavonoids in the twenty important 
indigenous high valued selected medicinal plants of Tirumala hills in Chittoor district of Andhra Pradesh based on ethnobotanical information collected from different tribal medicobotanical informants of Nakkala, Irula, Yanadi communities.

\section{Materials and Methods}

Twenty important indigenous high valued selected medicinal plants of Tirumala hills in Chittoor district of Andhra Pradesh was selected for the studies on the quantitation of flavonoids. Table 1 represents the plant taxa, parts used selected for the flavonoid screening were documented according to the Tribal informants' prescriptions and formulation.

Plant species were collected from different areas of Tirumala and was authentified by SKM Basha. The plant specimens were identified and plant nomenclature is given with the help of the floras of Gamble (1957), Rangacharyulu (1991), Pullaiah and Chennaiah, (1997) and Madhava Chetty et al., (2008). The final identification was confirmed by comparing the specimens with the authentic specimens available at various botanical institutions of Madras Herbarium $(\mathrm{MH}), \quad$ Coimbatore; Central National Herbarium, Howarah (CAL). All the mounted herbarium specimens were classified according to genera wise and were kept in species folders. The identified specimens were housed in the herbarium, department of botany, NBKR Medicinal Plants Research Centre, NBKR Science and Arts College, Vidyanagar, Nellore district.

Preparation of extracts were followed according to the methodology followed by Mitta et al., (2014). The crude water extract was used for the present study. Quantitative analysis of flavonoids was followed according to Manipal et al., (2017). The flavonoid compounds were extracted following the method of Markham (1982).
About $2 \mathrm{~g}$ plant powder was dried at $40^{\circ} \mathrm{C}$ and taken in a boiling test tube. This was added in $18 \mathrm{ml}$ of methanol and $2 \mathrm{ml}$ of water (9:1) shaken well and was kept for about 24 hours at room temperature. The upper clear solution of the extract was transferred to another test tube. To the remaining residue in the test tube, again $10 \mathrm{ml}$ of methanol and $10 \mathrm{ml}$ of water (1:1) was added, stirred well and the contents were kept for 24 hours. The clear extract thus obtained was pooled up with the earlier sample. The combined extract was mixed well and filtered through the cotton. Later the filtrate was evaporated to $1 / 3$ of the original volume and the resultant aqueous extract was taken into a separatory funnel and then extracted with $10 \mathrm{ml}$ of $\mathrm{CHCl}_{3}$. This process was repeated 3 to 4 times. All the chloroform extracts were combined and evaporated to dryness under vacuum in a rotary evaporator. Later the dried residue was dissolved in $1 \mathrm{ml}$ of $95 \%$ alcohol which was stored at low temperature in a dark until used.

Finally, few $\mathrm{ml}$ of water extract is added to conc. $\mathrm{HCl}$ and $\mathrm{Mg}$ powder. The presence of flavonoids can be identified by the development of pink or magenta or red coloured foam.

The chromatograms after unidimensional development were removed from the chromatographic chambers and dried at room temperature. The dried sheets were observed under U.V. light and the fluorescent spots were identified. The papers while being exposed to ammonia were observed under U.V light and the new fluorescent spots were also marked and sprayed with chromogenic spray reagents for the detection of flavonoid compounds. The flavonoid compounds were identified with their $\mathrm{Rf}$ values, colours and with those of authentic samples by cochromatographic techniques.

Solvents used for detection of flavonoids are 1) Iso-propyl alcohol: Ammonia (25\%): 
Water (8:1:1) and 2) Conc. Hydrochloric acid: Acetic acid: Water (3:30:10). Chromogenic spray reagents are a) Diazotized sulphanilic acid b) $1 \%$ Alcoholic aluminium chloride

\section{Results and Discussion}

A total of 20 taxa reported in the present study are selected for phytochemical investigation which are widely used by the various ethenic and folklore communities for curing numerous diseases or ailments, have yielded several therapeutic agents of known chemical structures are reported in detail in the present research work. Pictorial identity of HVM is given in figure 1.
Based on the $\mathrm{R}_{f}$ values and Colour reactions on paper chromatogram detection of flavonoids has been screened and identified. Table 2 represents the flavonoid screening according to the Retention factor value and colour obtained.

Solvents used for detection of flavonoids are 1) Iso-propyl alcohol: Ammonia (25\%): Water (8:1:1) and 2) Conc. Hydrochloric acid: Acetic acid: Water (3:30:10). Paper chromatogram studies revealed the occurrence of flavonoid compounds rutin, myricetin, quercetin, kaempferol, luteolin, apigenin, orientain and vitexin (Table 2 ).

Table.1 Selected HVM taxa of ethnobotanically used in and around Tirumala Hills

\begin{tabular}{|l|l|l|l|}
\hline Sl. No. & \multicolumn{1}{|c|}{ Botanical name } & \multicolumn{1}{|c|}{ Family } & \multicolumn{1}{c|}{ Part used } \\
\hline 1. & Polycarpaea corymbosa (L.) Lam. & Caryophyllaceae & Leaves \\
\hline 2. & Shorea tumbuggaia G.Don & Dipterocarpaceae & Bark \\
\hline 3. & Boswellia ovalifoliolata Bal. and Henry & Burseraceae & Paperry Bark \\
\hline 4. & Soymida febrifuga (Roxb.) A.Juss. & Meliaceae & Fruit pulp \\
\hline 5. & Indigofera barberi Gamble & Fabaceae & Complete plant \\
\hline 6. & Rhynchosia beddomei Baker & Fabaceae & Complete plant \\
\hline 7. & Sophora interrupta Bedd. & Fabaceae & Inflorescence \\
\hline 8. & Terminalia pallida Brindis & Combretaceae & Leaf + Fruits pulp (1:1) \\
\hline 9. & Syzygium altenifolium (Wight) Walp. & Myrtaceae & Inflorescence \\
\hline 10. & Opuntia dillenii (Ker.-Gawl.) Haw. & Cactaceae & Fruit + Flower $(1: 2)$ \\
\hline 11. & Trianthema decandra L. & Aizoaceae & Complete plant \\
\hline 12. & Gisekia pharnaceoides L. & Gisekiaceae & Leaf \\
\hline 13. & Enicostema axillare (Lam.) Raynal & Gentianaceae & Root \\
\hline 14. & Pisonia aculeata L. & Nyctaginaceae & Leaf \\
\hline 15. & Celosia polygonoides Retz. & Amaranthaceae & Immature Leaf \\
\hline 16. & Trichuriella monsoniae (Wight) Walp. & Amaranthaceae & Stem +Leaf $(1: 3)$ \\
\hline 17. & Polygonum glabrum Willd. & Polygonaceae & Complete plant \\
\hline 18. & Givotia moluccana (L.) Sreem. & Euphorbiaceae & Stem Bark \\
\hline 19. & Stemona tuberosa Lour. & Stemonaceae & Complete plant \\
\hline 20. & Smilax perfoliata Lour. & Smilacaceae & Leaf \\
\hline
\end{tabular}


Table.2 Flavonoids: $\mathrm{R}_{f}$ values and Colour reactions on paper chromatograms

\begin{tabular}{|c|c|c|c|c|c|c|}
\hline \multirow{2}{*}{ Compound } & \multicolumn{2}{|c|}{$\begin{array}{c}\mathbf{R}_{f} \text { values in } \\
\text { solvent }\end{array}$} & \multicolumn{2}{|c|}{ U.V. fluorescence } & \multirow{2}{*}{$\begin{array}{c}\text { Sulphanilic } \\
\text { reagent }\end{array}$} & \multirow{2}{*}{$\begin{array}{l}\text { 1\% Alcoholic } \\
\text { aluminium } \\
\text { chloride }\end{array}$} \\
\hline & 1 & 2 & Without $\mathbf{N H}_{3}$ & With $\mathrm{NH}_{3}$ & & \\
\hline Luteolin & 0.44 & 0.66 & Dull yellow & Yellow & Light red & Pale yellow \\
\hline Apigenin & 0.61 & 0.83 & Red brown & Red brown & Pink & None \\
\hline Orientin & 0.78 & 0.02 & Yellow & Yellow green & Grey & None \\
\hline Vitexin & 0.91 & 0.06 & Dull yellow & Yellow & Bright red & None \\
\hline Rutin & 0.03 & 0.35 & Orange brown & Yellow & Green & Yellow \\
\hline Muyricetin & 0.07 & 0.28 & Yellow & Bright yellow & Light green & Grey yellow \\
\hline Quercetin & 0.26 & 0.41 & Yellow & Light yellow & Bright yellow & Yellow \\
\hline Kaempferol & 0.37 & 0.54 & Green yellow & Bright yellow & Orange & Yellow \\
\hline
\end{tabular}

Table.3 Flavonoids detected in the selected HVM of Tirumala Hills

\begin{tabular}{|c|c|c|c|c|c|c|c|c|c|c|c|c|c|c|c|c|c|c|c|c|}
\hline Compound & 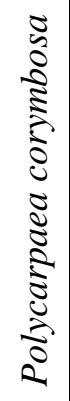 & 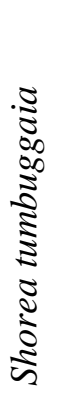 & 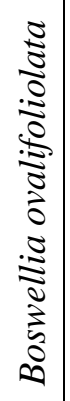 & 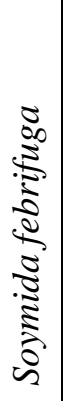 & 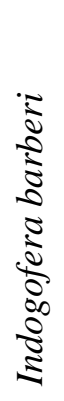 & 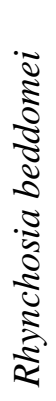 & 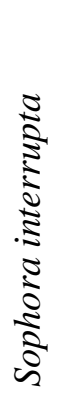 & 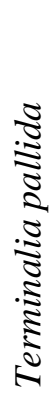 & 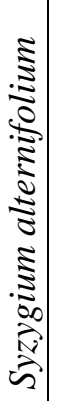 & 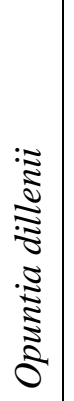 & 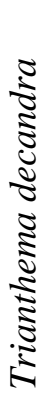 & 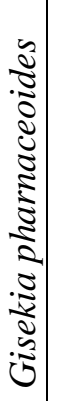 & 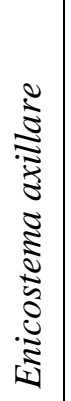 & 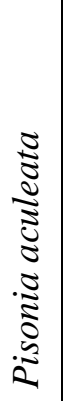 & 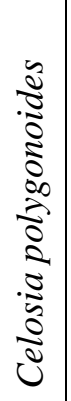 & 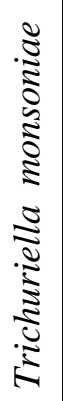 & 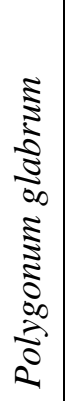 & 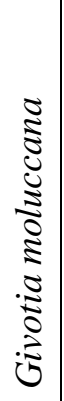 & 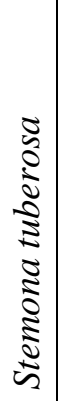 & 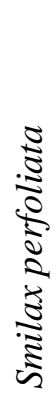 \\
\hline Rutin & + & + & + & + & + & + & + & + & + & + & + & + & + & + & + & + & + & + & + & + \\
\hline Myricetin & + & + & - & + & - & - & - & + & + & + & + & + & + & + & + & + & + & + & + & + \\
\hline Quercetin & + & + & + & + & + & + & + & + & + & - & + & + & + & + & + & + & + & + & + & + \\
\hline Kaempferol & + & + & + & + & - & - & - & + & - & + & + & - & + & + & + & + & + & + & + & + \\
\hline Luteolin & + & + & + & + & + & + & + & + & + & + & + & + & + & + & + & + & + & + & + & + \\
\hline Apigenin & - & + & + & + & + & + & + & + & + & + & + & + & + & - & - & + & + & - & - & - \\
\hline Orientin & + & - & + & + & - & - & - & - & - & + & + & + & + & + & + & + & + & + & + & + \\
\hline Vitexin & - & + & + & + & + & + & + & + & + & - & - & - & & - & - & - & - & - & - & - \\
\hline
\end{tabular}

$+=$ Present; - = absent 
Fig.1 High valued Medicinal Plants: A: Polycarpaea corymbosa; B: Shorea tumbuggaia; C: Boswellia ovalifoliolata; D: Soymida febrifuga; E: Indigofera barberi; F: Rhynchosia beddomei; G: Sophora interrupta; H: Terminalia pallida; I: Syzygium altenifolium; J: Trianthema decandra; K: Stemona tuberosa; L: Polygonum glabrum

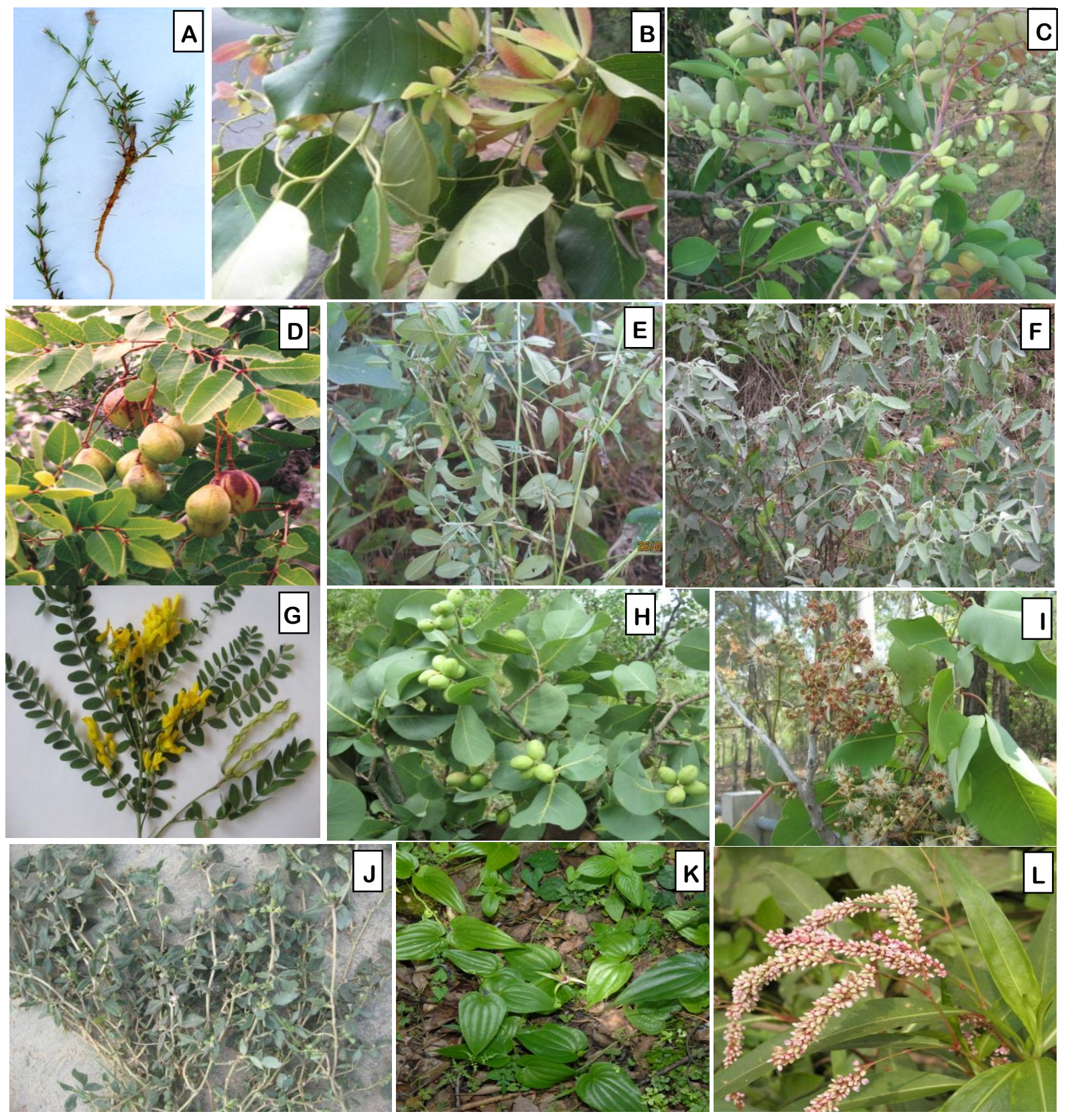


Table 3 represents the presence and absence of detected selected flavonoids in the extract of selected HVM viz., Polycarpaea corymbosa, Shorea tumbuggaia, Boswellia ovalifoliolata, Soymida febrifuga, Indogofera barberi, Rhynchosia beddomei, Sophora interrupta,Terminalia pallida, Syzygium alternifolium, Opuntia dillenii, Trianthema decandra, Gisekia pharnaceoides, Enicostema axillare, Pisonia aculeata, Celosia polygonoides, Trichuriella monsoniae, Polygonum glabrum, Givotia moluccana, Stemona tuberose and Smilax perfoliata.

It was reported that the concentration of flavonoids in plant extracts depends on the polarity of solvents used in the extract preparation. Soymida febrifuga contained all types of flavonoid compounds viz., rutin, myricetin, quercetin, kaempferol, luteolin, apigenin, orientin and vitexin.

Our previous investigations have revealed that the selected taxa are ethnomedico botanicals high valued plants which can be utilized for household medications and pharmaceutical formulations (Sree Latha Devi and Basha (2013a and b). Research works by Mahendranath et al., (2013) and Mitta et al., (2014) justifies that Total flavonoid contents and flavonoids show antioxidant activity and biochemical potency.

The plant medicines for internal use prepared in their traditional manner involve simple methods such as hot or cold water extraction, extraction of juice after crushing and powdering of dried material, formulation of powder into pastes or pills via such a vehicle as water, butter milk, oil, honey and even fermentation after adding a sugar sours. These traditional herbal medicines were being produced using age old methods by the practioners themselves who were able to identify the correct plant species.
Tirumala hills are a store house of very high valued medicinal plants of ethnobotanical information and it is true to extend the scientific efforts for thoroughly screening for phytochemical constituents. Shorea tumbuggaia, Boswellia ovalifoliolata, Soymida febrifuga, Indogofera barberi, Rhynchosia beddomei, Sophora interrupta, Terminalia pallida, Syzygium alternifolium are some of the rare and endangered plants of Tirumala Hills. This research on screening of flavonoids in 20 selected taxa indicate that the flavonoids act as identification markers of genuinity in evaluation of ethnobotanicals and herbal drugs in the markets against adulterations also.

In conclusion this investigation revealed and proved to be highly beneficial which are used by the different ethnic and rural communities for a variety of diseases which proved that the tribal informants prescribed botanicals proves to be flavonoid rich potent phytomedicine. The present survey makes an important addition to the growing knowledge on ethnomedicobotany. When such high valued medicinal plants are frequently used, they may become rare, endangered, and even extinct in no time. So there must be a strong measure of conservation strategy to protect High valued medicinal plants for future generations for use.

\section{Acknowledgement}

The authors acknowledge Department of Botany, Rayalaseema University for granting registration, facilities and permission to carryout this research work.

\section{References}

Kumar S and Pandey AK (2013). Chemistry and Biological Activities of Flavonoids: An Overview. The Scientific World Journal. 162750, pp $1-16$. 
Madhavachetty K., Sivaji K and Tulasi Rao K. (2008). Flowering plants of Chittoor District, Andhra Pradesh, India. $1^{\text {st }}$ edition. Student offset Printers, Tirupati.

Mahendranath M, Santosh CH, Madhava chetty K (2013). Antioxidant Activity And Its Correlation Of Different Solvent Extracts Of Male Cones Of Cycas beddomei Dyer, endemic taxa to Seshachalam biosphere reserve. International Journal of Pharma and Bio Sciences 4(4): (B) 1394-1403.

Manipal K, Lagisetty R, Chetty KM (2017) Quantitation of Flavonoids in Barks of Selected Taxa of Combretaceae. Pharmacy and Pharmacology International Journal 5(1): 00111.

Markham RK. (1982). Techniques of flavonoid identification, Academic Press, Inc. (London) Ltd.

Mitta MN, M Sankara Rao, L. Ramesh, K Madhava Chetty (2014) Phyto-
Chemical Evaluation and Anti-oxidant potentiality of Cycas beddomei Dyer Male cone aqueous Extract. International Journal Drug Development and Research 6 (2): 220227.

Pullaiah T and Chennaiah E (1997). Flora of Andhra Pradesh, Vol:1-3, Scientific Publishers, Jodhpur.

SreeLatha Devi RK and Basha SKM (2013a). Ethno Medico Botanical studies of High valued Medicinal plants of Tirumala Hills, Eastern Ghats, Andhra Pradesh. Indian Journal of Fundamental and Applied Life Sciences. 3 (1): 198-202.

SreeLatha Devi RK and Basha SKM (2013b). Antioxidant Activity And Total Polyphenols Content Of Certain High Valued Medicinal Plants Of Tirumala Hills, Andhra Pradesh. Indian Journal of Plant Sciences. 2 (1) 93-98.

\section{How to cite this article:}

Sreelatha Devi, R.K., and Basha, S.K.M. 2017. Screening of Flavonoids in Selected High Valued Medicinal Plants (Hvm) of Tirumala. Int.J.Curr.Microbiol.App.Sci. 6(4): 2844-2850. doi: https:// doi.org/10.20546/ijcmas.2017.604.326 